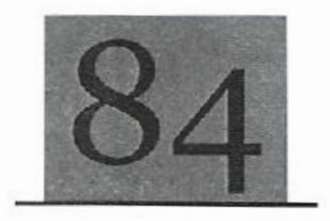

\title{
Haematological changes in the blood of Clarias gariepinus fed Chrysophyllum albidum seedmeal replacing maize
}

\author{
Jimoh, W. A. / Ajasin, F. O./Adebayo, M. D./ Banjo, O. T. /
}

Rifhat, A. O./ Olawepo, K. D.

\begin{abstract}
This study was conducted to investigate growth response of C. gariepinus fed diets containing $C$. albidum seed-meal repiacing maize. Five isonitrogenous diets containing maize which was replaced by $\mathrm{C}$. albidum at a rate of $0,25,50,75$ and $100 \%$ were made. The diet without $C$. albidum seed-meal served as the control. Experimental diets were assigned randomly to the tanks and each group of fish was fed $5 \%$ body weight in equal proportion per day. The fish fed diet 1 had the highest $P C V$ while the fish fed diet 3 had the lowest $P C V$. There was significant difference $(p<0.05)$ in the $P C V$ of the fish fed various dietary treatments. However; there was no significant difference $(p>0.05)$ in the $P C V$ of the fish fed diet 2 , diet 3 , diet 4 , diet 5 . A similar trend as observed for PCV was also observed for $H b, R B C, M C V, M C H$ and $M C H C$. There was no significant difference $(p>0.05)$ in the WBC of the blood of the fish fed various dietary treatments so also were neuirophyls and lymphocytes.
\end{abstract}

Keywords: C. gariepinus, C. albidum, maize, dietary treatment.

\section{Introduction}

$A$ review of the animal and aquafeed industries in Nigeria made by Fagbenro and Adebayo (2006) revealed that most cattish feeds are farm made, using locally available ingredients such as maize, soybean, fish meal, blood meal, rice bran, fish oil, etc. Olurin et al. (2006) reported that maize is the major source of metabolizable energy feed ingredient in most compounded diet for catfish species. This is because it is readily available and digestible. However, the increasing prohibitive cost of this commodity has necessitated the need to search for alternative ingredients that will serve as a replacement. Moreso, that FAO (2005) reported insufficient quantities of maize that are produced in Nigeria were predominantly used for human consumption. Osuigve (2005) reported that high cost and scarcity of maize in formulated diet has led to the use of under utilised energy sourees; such as cassava root meal, wheat bran, sorghum meal.

Chrysophyllum albidum, from the Sapoleacea family is commonly found in the Central Eastern and Western Africa (Amusa et al., 2003). They are distributed in Nigeria, Uganda. Niger, Cameroun, and Cote d'Ivoire. It is often called the white-star apple and distributed throughout southern Nigeria (Idowu et al., 2006). Across Nigeria, it is known by several local names; in the southwest the fruit is called "agbalumo," "udara" in the southeast and is gencrally regarded as a plant with diverse ethno-medicinal uses (Amusa et al., 2003). Svobodova et al. (1991) opined that ichthyohemotology would be useful in the assessment of suitability of feeds and feed mixture, evaluation of fish condition, determination of toxic effect of substances, as well as diagnosis of disease. The use of hematological values as indices of diagnosing diseases and stress induced condition as well as for feed assessment is well documented (Fagbenro et al., 1993, Adeparusi and Ajayi, (2004), George et al., 2007 Yue and Zhou; 2008, Akintayo et al., 2008). This work therefore seeks to study the hematological response of $C$. gariepinus fed diet containing $C$ albidum seed-meal.

\section{Materials and Methods}

: Seed collection and processing. Dried matured Chrysophylum albidum seeds were obtained from Bodija Market, Ibadan Oyo State and they were processed by boiling in water $\left(100^{\circ} \mathrm{C}\right)$ for 30 minutes. They were prepared by grinding the samples in a laboratory mill, then mechanically defatted by the use of locally made screw press, and sieved with a $200 \mathrm{~mm}$ mesh size sieve, before putting in polyethylene bags and stored at $4^{\circ} \mathrm{C}$. The cakes, there- 
fore, were analyzed for their proximate composition (AOAC 1990). Fish meal, soybean meal and other feedstuffs obtained from commercial sources in Nigeria were separately milled screened to fine particle size, and triplicatc samples were analyzed for their proximate composition (AOAC, 1990). Based on the nutrient composition of the protein feed stuff (Table 1), a control diet and four test diets were formulated. The control diet contained maize which was replaced by cooked $C$. albidum seed meal. The rate of substitution was $0,25,50,75$ and $100 \%$ (Table 2).

Table 1: Proximate composition of the protein feed ingredients.

\begin{tabular}{l|c|c|c|c}
\hline Parameter & Fish meal & Soybean meal & \multicolumn{1}{c}{ CSM } & Corn meal \\
\hline Moisture & 9.75 & 10.70 & 9.10 & 10.48 \\
Crude protein & 72.4 & 45.74 & 10.95 & 9.87 \\
Crude lipid & 10.45 & 9.68 & 2.94 & 4.28 \\
Crude fibre & - & 5.10 & 3.06 & 5.78 \\
Ash & 8.32 & 4.48 & 2.12 & 6.73 \\
NFE & - & 30.00 & 71.83 & 62.35 \\
\hline \multicolumn{2}{r|}{ CSM-Chrysophyllum albidum seedmeal }
\end{tabular}

Table 2: Gross composition of experimental diets $(\mathrm{g} / 100 \mathrm{~g})$ containing $C$. albidum seedmeal fed to $C$. gariepinus.

\begin{tabular}{l|c|c|c|c|c}
\hline & D1 & D2 & D3 & D4 & D5 \\
\hline Fishmeal (72.4\%) & 52.78 & 52.78 & 52.78 & 52.78 & 52.78 \\
Corn meal (10.48\%) & 20.00 & 15.00 & 10.00 & 5.00 & - \\
CSM(10.95\%) & - & 4.56 & 9.13 & 13.69 & 18.25 \\
*Vitmin premix & 5.00 & 5.00 & 5.00 & 5.00 & 5.00 \\
Fish Oil & 5.00 & 5.00 & 5.00 & 5.00 & 5.00 \\
Starch & 17.22 & 17.66 & 18.09 & 18.53 & 18.97 \\
Total & 100 & 100 & 100 & 100 & 100 \\
\hline
\end{tabular}

C5M- Chrysophyllum albidum seedmeal. *Specification: each kg contains: Vitamin A, 4,000,0001L; Vitamin B, 800,0001U; Vitamin E, $16,000 \mathrm{mg}$, Vitantin $K_{3}, 800 \mathrm{mg}$; Vitamin $B_{1}, 600 \mathrm{mg}$; Vitamin $B_{2}, 2,000 \mathrm{mg} ;$ Vitamin $B_{i,} 1,600 \mathrm{mg}$, Vilamin $B_{1,2} 8 m g ;$ Niacin, 16,000mg; Caplan. 4,000mg; Folic Acid, 400mg; Biotin, 40ms; Antioxidant 40,000mg; Chlorine chloride, 120,000mg; Manganese, 32,000mg; Iron 16,000mg; Zinc, 24,000mg; Copper 32,000mg; Iodine 320mg; Cobalt, 120mg; Selenitum, 800mg manufactured by DSM Nutritional Products Europe Ltâ., Basle.

- Culture condition. $C$. gariepinus fingerlings were acclimated to experimental condition for 7 days prior to the feeding trial. Groups of 15 catfish fingerlings were stocked into aquaria comprising 60 litre-capacity rectangular plastic tanks. Each diet was fed to the catfish in triplicate tanks twice daily $(09.00 \mathrm{~h}, 16.00 \mathrm{~h})$ at $5 \%$ body weight for 56 days. Fish mortality was monitored daily, total fish weight in each tank was determined at two weeks intervals and the amount of diet was adjusted according to the new weight.

- Hematological studies. The blood analyses were determined according to the method described by Svobodova et ai. (1991). The following were done.

- Blood analysis. $5-10 \mathrm{ml}$ blood samples were collected from cardiac puncture using $2 \mathrm{ml}$ disposable heparinised syringe treated with EDTA as anticoagulant.

- Blood cell count. Haemocytometer was used in blood cell count. The blood diluting fluid was prepared as described by Svobodova et al. (1991). The blood cells were counted on the counting chamber of haemocytometer with the aid of compound microseope.

- $\mathrm{RBC}=$ No of cells counted $\times 3 \times 10 \times 200\left(10^{6} \mathrm{~mm}^{3}\right)$

- $\mathrm{WBC}=$ no of cells counted $\times 0 \times 25 \times 10 \times 20\left(10^{4} \mathrm{~mm}^{3}\right)$

- Hemoglobin estimation. Haemoblobinometer was used for hemoglobin estimation based on acid haematin method (SAILI)

Packed Cell Volume

$$
\text { Hemoglobin }=\frac{\text { Value obtained } x 17.2 \mathrm{mg} / 100 \mathrm{ml}}{100}
$$

The packed cell volume was measured after placing sealed microhaematocrit tube in a centrifuge at $10,500 \mathrm{rpm}$ using microhaematocrit reader and expressed as percentage.

Mean Corpuscular Volume (MCV) was calculated from the haematocrit valne (PCV, \% and the Erythrocyte count (Er mm ${ }^{3}$ )

$\operatorname{MCV}\left(\mu^{3}\right)=\operatorname{PCV} \times 10 \mathrm{Er}$

Mean corpuscular hemoglohin concentration (MCHC).

This was obtained using the formula $M C H C(\%)=\frac{b H \mathbb{D}^{2}}{P C V}$

Mean Corpuscular Hemoglobin (MCH). This was expressed in picogrammes $(\rho g)$ 


$$
\operatorname{MCH}(B)=\frac{H \times \mathbb{Q}^{2}}{E}
$$

- Statistical analysis. Data obtained from the experiment was expressed in mean $\pm \mathrm{SD}$ and it was subjected to one way Analysis of Variance (ANOVA) using SPSS 16.0 version. Where the ANOVA reveals significant difference $(\mathrm{P}<0.05)$ Duncan multiple range test was used to compare differences among individual treatment means.

Results

- Proximate composition of the experimental diets. Table 3 shows the proximate composition of the cxperimental diets. It reveals the diets to be isonitrogenous and isolipidic as there was no significant difference $(p>0.05)$ in the crude protein and erude lipid content of the diet. The protein and lipid requirement of $C$. gariepinus was met by the 40 and $12 \%$ provided in the experimental diets. All the fish responded well to the dietary treatment given to them.

Table 3: The proximate composition of experimental diets containing $C$. albidum seed meal fed to $C$. gariepinus

\begin{tabular}{l|l|l|l|l|l}
\hline Parameter & $D 1$ & $D 2$ & $D 3$ & $D 4$ & $D 5$ \\
\hline Moisture & $9.24 \pm 0.11$ & $9.20 \pm 0.03$ & $9.16 \pm 0.13$ & $9.12 \pm 0.10$ & $9.23 \pm 0.06$ \\
Crude protein & $40.23 \pm 0.05$ & $40.20 \pm 0.08$ & $40.25 \pm 0.15$ & $40.23 \pm 0.06$ & $40.20 \pm 0.12$ \\
Crude lipid & $12.17 \pm 0.09$ & $12.20 \pm 0.05$ & $12.15 \pm 0.12$ & $12.16 \pm 0.08$ & $12.20 \pm 0.13$ \\
Crude fibre & $4.59 \pm 0.45$ & $4.15 \pm 0.11$ & $4.16 \pm 0.10$ & $4.16 \pm 0.05$ & $4.13 \pm 0.05$ \\
Ash & $4.48 \pm 0.06$ & $4.60 \pm 0.45$ & $4.50 \pm 0.32$ & $4.33 \pm 0.40$ & $4.37 \pm 0.31$ \\
Nie & $29.29 \pm 0.31$ & $29.71 \pm 0.51$ & $29.80 \pm 0.50$ & $29.10 \pm 0.40$ & $29.93 \pm 0.30$ \\
\hline \multicolumn{5}{c}{ Rew means without superscript are not significantily different (p>0.05) from one another. } \\
\cline { 2 - 5 }
\end{tabular}

- Haematological profile. Table 4 shows the haematological profile of $C$. gariepinus fed diet containing $C$. albidum seedmeal. The fish fed diet 1 had the highest PCV while the fish fed at diet3 had the lowest PCV. There was significant different $(p<0.05)$ in the PCV of the fish fed various dietary treatments. However, there was no significant difference $(p>0.05)$ in the PCV of the fish fed diet2, diet3, diet4, diet5. Similar trends as observed for PCV were also observed for IIb, RBC, MCV, MCH and MCHC. These was no significant difference in the WBC of the blood of the fish fed various dictary treatment so also were neutrophyl and lymphocyte.

Table 4: The haematological profile of Clarias gariepinus fed diet containing Chrysophyllum albidum seedmeal.

\begin{tabular}{l|l|l|l|l|l}
\hline & D1 & D2 & D3 & D4 & D5 \\
\hline PCV & $25.67 \pm 3.21^{\mathrm{a}}$ & $12.00 \pm 1.00^{\mathrm{b}}$ & $11.67 \pm 0.58^{\mathrm{b}}$ & $12.67 \pm 3.06^{\circ}$ & $12.00 \pm 1.00^{\mathrm{b}}$ \\
\hline HB & $8.60+1.13^{\mathrm{a}}$ & $4.00 \pm 0.20^{\mathrm{b}}$ & $3.93+0.12^{\mathrm{b}}$ & $4.23 \pm 0.97^{\mathrm{b}}$ & $4.00 \pm 0.20^{\mathrm{b}}$ \\
\hline RBC & $2.25 \pm 0.28^{\mathrm{a}}$ & $1.05 \pm 0.09^{\mathrm{b}}$ & $1.04 \pm 0.05^{\mathrm{b}}$ & $1.11 \pm 0.27^{\mathrm{b}}$ & $1.06 \pm 0.11^{\mathrm{b}}$ \\
WBC & $142.93 \pm 6.22$ & $140.57 \pm 8.26$ & $177 \pm 61.82$ & $190.23 \pm 78.30$ & $133.83 \pm 12.91$ \\
\hline Neutrophyl & $64.33 \pm 4.04$ & $60.00 \pm 5.00$ & $65.67 \pm 11.60$ & $70.33 \pm 10.50$ & $31.70 \pm 2.90$ \\
Lymphocyte & $35.67 \pm 4.07$ & $40.00 \pm 5.00$ & $34.33+11.59$ & $29.67 \pm 10.50$ & $31.67+2.89$ \\
\hline MCV & $99.10 \pm 12.44^{\mathrm{a}}$ & $46.33 \pm 3.85^{\mathrm{b}}$ & $45.03 \pm 2.19^{\mathrm{b}}$ & $48.90+11.82^{\mathrm{b}}$ & $46.33 \pm 3.85^{\mathrm{b}}$ \\
MCH & $30.77 \pm 4.05^{\mathrm{a}}$ & $14.30 \pm 0.70^{\mathrm{b}}$ & $13.97 \pm 0.35^{\mathrm{b}}$ & $15.17 \pm 3.48^{\mathrm{b}}$ & $14.30+0.70$ \\
\hline MCHC & $23.133 \pm 2.84^{\mathrm{a}}$ & $10.80 \pm 0.90^{\mathrm{b}}$ & $10.70 \pm 0.46^{\circ}$ & $11.40+2.72^{\mathrm{b}}$ & $10.73 \pm 1.06^{\mathrm{b}}$ \\
\hline
\end{tabular}

Rows means with the same superscript are not significantly different from each other $(p<0.05)$.

\section{Discussion}

The result of the proximate analysis of the diets to be isonitrogenous and isolipidic. The protein and lipid requirement of $C$. gariepinus was met by the quantity provided in the diets. Uys and Hetch (1985) reported that the best growth rate and feed conversion efficiency in juvenile and sub-adult $C$. gariepinus are achicved with diets containing $38-42 \%$ crude protein and optimum liquid content of $10-11 \%$.

The observed reduction in haematological parameters in $C$. gariepinus $\mathrm{fed} C$. albidum meal in this study conform to the report of Tacon (1992) and Jimoh 2012that nutritionally deficient diets can cause decrease in haemoglobin content, reduced PCV, and red blood cell count. The decrease in haematological parameters with increasing level of incorporation of $C$. alhidum meal agreed with the obscrvation of Blom et al. (2001); Dabrowski et al. (2001); Richard et al. (2003) and Fagbenro et al. (2010. However, the values recorded for RBC, of the fish fed the dietary treatments were all within the range of normal haematology of a healthy fish (Fagbenro et al., 1993; Rastogi, 2007). Erythrocyte count greater than $1 \times 10^{6} / \mathrm{mm}^{3}$ is considered high and is indicative of high oxygen carrying capacity of the blood which is characteristic of fishes capable of aerial respiration and with high activity. The PCV values recorded in this study fall within the normal range of $20-38 \%$ for fish as reported by Clarke et al. (1979) and Erondu et al. (1993).

Increase in white blood cell as observed in the fish fed $\mathrm{C}$. albidum diets is attributed to increase in the production of leucocyte in the haemotopoietic tissue of the kidney and perhaps the spleen. Akinwande et al. (2004) reported that a measur- 
able increase in WBC of fish is a function of immunity response to vulncrable illness and disease. Thus it can be concluded that not much stress is placed on the health of C. gariepinus fed C. albidum seed meal replacing soybean meal

\section{REFERENCES}

Adeparusi, F. O. and Ajayi, A. D. (2004) Haematological characteristics of Nile Tilapia (Oreochromis niluticus) fed differently processcd lima bean (Phase'olus hanatus) diets. Joumal of Research in Science and Management, 2'1: 73-80.

Akintayo, I. A., Obasa, S. O., Alegbeleye, W. O. and Bangbose, A. M. (2008): Evaluation of toasted sunlower (Helianthus anmus) seed meal in the diets of African catfish (Clarias garieninus) fingerlings. Vol. 20, Article Vo. 157. http://www:Irrd.org/1rd20/10/ akin2015?.html.

Akinwande, A. A. Moody, F. O., Snghesan, O. A., Ugwumba, A. A. A. and Ovie, S. O (2004). Haematological reponse of Hcterobranchus iongifilis fed varying dietary protein levels. Procecdings, 19th FISON Anmual Conferenc, Ilorin, 715-718.

Amusa, N. A., Ashaye, O. A and Oladapo, M. O. (2003). Biodeterioration of the African star apple (Chrysophyllum aibidum) in storage and the eflect on its fond value. Afr. S. Biotechnol. 2 (3): 56-59.

AOAC (1990). Official Methocis of Analysis. K. Helrich (cd). 15th edn. vol. 1, Association of Official Analytical Chemists. Arlington, Virginia, $684 \mathrm{pp}$.

Blom, J. H., Lee, K. J. Richard, J., Dabrowski, K. and Ottobre, J. (2001): Reproductive efficiency and maternal offspring transfer of gossypol in rainbow troul (Oncorhynchus myliss) fcd diets containing cottonseed meal. J. Anim Sci. 79, 1533-1539.

Clark, S., Whitemore, D. H. (Jr.) and McMahon, R. F. (1979). Consideration of blood parametcrs of largemouth bass (Micropteres salmoides). J. Fish Biol. 14: 147-154.

Dabrowski, K., Lee, K. J., Richard, J.. Geresko, A., Blom, J. H. and Ottobre, J. S. (2001). Gossypol isomers bind specifically to blood plasma proteins and spermatozoa of rainbow trout fed diets containing cottonseed meal. Biochem. Biophys. Acta 1525, 3742.

Erondu, E. S., Nnubia, S. and Nwadukwe, F. O. (1993). Haematological studies on four catfish species raised in freshwater pond in Nigeria. J. Appl. leih. $9(3-4): 250-256$.

Fagbcnro, (). A., Adeparusi, E. O and Jimoh, W. A. (2010). Haematological profile of blood of African catfish (Clarias gariepinus) fed sunflower and sesane meal based diet. Pruceedings, 25th FISON Annual Conference, Badagry, October 25-29.

Faghenro, O. A., Adedire C. O., Owoseeni, E. A. and Ayotunde, E. O., (1993): Studies on the biolngy and aquaculture potential of feral cattish Heterobranchus bidorsalis. Tropical Zoology 6:67 79

Adebayo, O. T. (2006) A review of the animal aquafeed industries in Nigera. Mohel, J. and Halwart, M. (eds). A synthesis of the formulated animal and aquafeeds industry in sahuran Africa. CIF1 Occasionai Paper No. 26. Rome. TAO. 61p

George, F. O. A., Ohasa, S. O. and Otubusin, S. O. (2007). (irowth response and carcass quality of African cattish fed multi-enzymesupplemented soybean meal dicts. Appl. Trop. Agric. 12/1-2:51-59.

Idowu, T. O., Iwalewa, E. O., Aderogba, M. A., Akimpelu, B. A. and Ogundaini, A. O. (2006). Biochemical and behavioral effects of cleagnine from Chrysophyitum alhidum. J. Biol. Sci, 6, 10291034.

Jimoh, W. A. (2012). Nutritive value of sesume (Sesamum indicum) or sunflower (Helicmihts annuus) seedmeals as dietary protein sources for African catfish. PhD Disserlation. Federal University of lechnology, Akure. 265pp.

Olurin, K. B., Olojo, E. A. A., Olukoya, O. A. (2006). Grow th of African carfish Clarias gariepimus fingerlings fed different levels of cassava. Internationa! Digita? Organization for Scientific Information, 1i1: 5456.

Osuigwe, D. I., Obejezie, A. I. and Onuoha, G. C. (2005). Some haematological changes in hybrid calfish fed different levels of raw and boiled jackbean (C. ensiformis), Afr. J. of Bistechiology 4: 1017-1021.

Rastogi, S. C. (2007). Essenials of Animal Physiciogy. New Delhi: New Age International Ltd, 597.

Richard, J., Lee K. J, Czesny, S., Cierešku, A., Dahrowski, K. (2003). Effect of feeding cottonseed meal containing diets to broodstock rainhow trout and their impact on the growth of their progenies. Aquacuiture 22?, 7?-87.

Svobodova, Z, Pravda, D. and Palackuva, J. (1991). Unified methods of hematological examination of fish. Rcsearch Institute of Fish Culture and Hydrobiology, Vodnany, Czechoslovakia, 31.

Tacon, A. G. J. (1992). Nutritional fish pathology: morphological signs of nutrients deficiency and toxicity in farmed fish. FAO Fisheries Technical Paper No. $330 \mathrm{FAO}$, Rome 75p.

Uys, W. and liecht, T. (1985): Evaluation and preparation of a suitable dry feed and optimal fecding frequency for primary nursing of C. gariepinus larvae. Aquaculture 47:173-183.

Yuc, Y.-R. and Zhou, Q. C. (2008). Fffect of replacing soyhean meal with cotton seed meal on growth, feed utilization and hacmatolngical indexes for juvenile hybrid tilapia Oreochromis niloticus x O. anrous, Aquaculture 284: 185-189. 